\title{
Navigating "place" in evaluation design and practice
}

\section{Maxine Dignan}

To feel a sense of place is a fundamental human need and in order to understand people's experiences, it is critical to understand their place. This is particularly important in the rural, bicultural communities of Aotearoa New Zealand, many of which have not been well served by research and evaluation. Place consciousness is not a new concept in evaluation theory, particularly as an aspect of cultural and contextual responsiveness. However, the concept of place is not easily defined or well articulated in relation to evaluation theory and practice. This article reflects on the findings of the author's 2014 literature review, which focused on the concept of place and its implications for evaluation design. The author promotes a place-conscious approach to evaluation that recognises and honours features of the places where people live their lives. A place-conscious evaluation requires evaluators to consciously assess the implications of place and pay explicit attention to place-connected knowledge. It provides a foundation for evaluators to work collaboratively with communities to enhance evaluative thinking and develop more meaningful, relevant, and useful evaluation insights as a basis for positive action. 


\section{Navigating place in evaluation design and practice}

As a New Zealander whose ancestry includes both $\mathrm{Ngāpuhi}^{1}$ and early farming pioneers, I have a keen sense of place that is fundamental to my sense of identity. I was raised in a community alongside the Whangaroa harbour, in Te Tai Tokerau, the far north of Aotearoa New Zealand. Māori and Pākehā have lived and worked alongside each other in this community for more than 200 years.

I have often been told by my relations and old school friends who reside in the communities of this historic, rural, bicultural area, that research and evaluation have never made any difference for them. "Academics don't understand us," they have said. They feel that no-one listens to them. They have been misrepresented by researchers in the past and in their experience, research and evaluation have not resulted in positive change. These views are recognised by Mertens (2015, in Cram \& Mertens, 2016). The stories I heard, and my own experiences as an evaluator in communities like this, led me to explore the concept and implications of place, why it matters, and how we might respond as evaluators.

Māori evaluators have told me about place in relation to maunga, awa, iwi, hapū, whakapapa, tūpuna, kaumātua, marae, wairua, and whanaungatanga (see glossary). Māori understand the concept of place from a Māori world view, as expressed in their pepeha. They have a relationship with maunga as tūpuna, and recognise the obligations of whānau and marae. Tūrangawaewae is a necessary condition of wellbeing. The mana of tūpuna Māori permeates the land, and identification with ancestral features of the land verifies their status as tangata whenua (Brown, 2014; Cadogan, 2004; Urlich Cloher, 2004). Sadler says, "we cleave to this land from the beginning of the world itself" (Independent Panel, 2012, p. 28). During a 2009 event

1 Ngāpuhi is the Māori tribal group centred in the Northland region of Aotearoa New Zealand. 
on the Whangaroa harbour, Bishop Kito Pikaahu quoted a Ngāpuhi whakataukī, saying, "the maunga don't go anywhere; they stay where they are, as pou for the people who come and go" (see also Todd, 2012). Cram and Mertens articulate the Māori world view of connectedness with the natural environment. They note that whanaungatanga, whakapapa, and pepeha locate Māori "in a three-dimensional landscape” (Cram, Kennedy, Paipa, Pipi \& Wehipeihana, 2015, p. 297, in Cram \& Mertens, 2016, p. 173). These Māori perspectives reflect how I feel about the significance of Whangaroa as my spiritual home, where many of my ancestors lived and are buried.

I feel strongly that to know me (or to evaluate my practice) it is necessary to understand where I come from and my relationships with and in that place. This view is expressed by Friere (in Johnson, 2010, p. 835), when he tells us that "to engage with community requires us to engage with place". Penetito (2009) also challenges us to think more about the relationships between place and identity. However, in evaluations in the rural bicultural communities that have been my focus, an intentional and clearly articulated response to place in evaluation design does not seem to be common practice. I therefore set out to investigate the potential for a greater consciousness of the places where people live their lives, to improve the relevance and usefulness of evaluation for communities like my own. I wanted to find out whether:

- a better knowledge about place could provide more robust information for evaluation design and planning

- a greater sensitivity to place could increase the likelihood that evaluation would make a difference for the people

- place-conscious evaluation could contribute positively to policy decisions that affect communities. 
I found that evaluation theorists often include place as a critical aspect of context. The influence of place on methodology has been recognised since 1958 (Arendt, in Greene, 2005). However, the concept of place is not well articulated in evaluation research. I began to explore evaluation theorists' views about the importance of responding to context as a starting point for examining place as an element of context, and for considering how consciousness of place can deepen the evaluator's understanding of the context of their work.

\section{The centrality of context in evaluation}

We know that context grounds all aspects of indigenous evaluation (LaFrance, Nichols, \& Kirkhart, 2012) and that, in indigenous contexts, programmes are understood within their relationship to place, setting, and community. In an indigenous evaluation framework, evaluations are planned, undertaken, and validated in relation to cultural context. Context moves from "character role to leading role" (LaFrance, Nichols, \& Kirkhart, 2012, p. 73).

Many authors promote responsiveness to context as a precondition of quality evaluation practice. However, Rog, Fitzpatrick and Conner (2012) note that there are many gaps in evaluators' understanding of context. They argue that there continues to be a lack of unified theory or conceptualisation about the individual elements of context. These authors challenge evaluators to "navigate the black hole of context" (pp. 1-2). They talk about bringing background to foreground; bringing context to the front of our thinking. Increased sensitivity to context, they assert, can improve the quality of evaluation practice, build evaluation capacity, and increase the likelihood that evaluation will make a difference for stakeholders. These authors talk about context as a force that shapes our evaluation practice and influences how we approach, design, and carry out our evaluations. Other authors also argue the significance of context and express the 
need for a more sophisticated conceptualisation of how it matters in evaluation (Dahler-Larsen \& Schwandt 2012; Greene, 2005; Neuman, 2006; Ward, Maher, Marcynyszyn, Ellis, \& Pecora, 2011). They note the impact that context exerts, and the importance of putting context ahead of method choice.

The evaluation community is challenged to consider where we still need to go in defining, conceptualising, and elaborating on context (Rog, Fitzpatrick, \& Conner, 2012; Greene, 2005). Therefore, if place is a critical element of context, it is important to understand what is meant by this concept.

\section{Why think about place?}

Gruenewald (2003) describes the world we live in as a place where relationships amongst humans are poorly understood and increasingly strained. It is in places, he says, that these relationships are experienced and where they can be examined; they teach us how things work and how we fit into the spaces we occupy (pp. 621645). An understanding of place, according to Gruenewald, is key to understanding the nature of our relationships with one another. "We should learn to listen to what places are telling us and respond as informed, engaged citizens" (p. 645). Gruenewald argues that place consciousness complicates the single-minded pursuit of accountability-it insists on a connection between our activity and the places that we live and work in. He talks about interrogating the power of place as a construct for analysis. Johnson and Larsen (2013) argue that we are marked by the landscapes we inhabit and that they inevitably follow us into our interactions with others. The importance of place as an active participant in collaboration, they say, "cannot be underestimated" (Johnson \& Larsen, 2013, pp. 14, 15).

The literature suggests that the philosophy of place remains obscure because our experience of it is so commonplace; because it 
can be taken for granted and disappear from view. Evaluators are challenged to make the ordinary more visible (Gruenewald, 2003, p. 622; Penetito, 2009, p. 6). If it is true that "we cannot say we know something until we understand the effects of this knowledge on real people and their communities" (Orr, in Penetito, 2009, p. 19), how can we go about our evaluation work with a greater level of consciousness about where we are; the place where the evaluand is situated?

Having found that place is often included as an element of context, and that the concept is not explicitly unpacked in evaluation literature, my next step was to establish a deeper understanding about place, before considering how it should influence evaluation design and practice.

\section{Towards a working understanding about place}

I began to delve into the notion of place; the multidimensional connections between place and identity, self-perception and community; and then what place means for evaluation. I wanted to understand more about the world view of the people I work with, through an understanding of their place. As I had found little information about place in evaluation research, I also explored Māori and indigenous research. I then found rich information about place in geography and rural studies research. I looked particularly for information that related to rural, bicultural communities such as those in Te Tai Tokerau.

Rather than simply seeking to define place, many authors explore its meaning, and emphasise its importance and significance to people. They argue that a sense of place is crucial to identity, belonging, and wellbeing. For example, Penetito (2009) notes that a sense of place is a fundamental human need, a message of connectedness and inter-relatedness (p. 21). Windsor and McVey (2005) assert that "the importance of place and sense of place to human wellbeing cannot be 
overstated" (pp. 147-148). They describe place as "a location where the people have long memories reaching back beyond bygone generations" (p. 148). Johnson (2010) shares experiences of communities, grounded in shared histories, stories and challenges, and based within a politics of place. He sees place as location; "the locale and scale of everyday life - a way of understanding and knowing about the world ... in a location endowed with meaning" (p. 829).

It became apparent through the literature that a personal and collective sense of place is significant for both indigenous and nonindigenous peoples, in Aotearoa New Zealand and elsewhere.

\section{An indigenous perspective of place}

Indigenous research tells us that place is about our identity. It is where we belong, where we return home, where we know its stories and ways, where the spirits of the place know us, and where we are kept together within its mountains; a bridge between generations (Windsor \& McVey, 2005). The place itself is sustenance for body and soul, imbued with memories, commitments made, and obligations met, where people and environment are co-habitors (Penetito, 2009). Writers talk about a sense of responsibility in and to place, about spiritual, emotional, historical, cultural and practical connectedness, and the notion of being and becoming, as well as of identity (Coombes, 2013; Penetito, 2009).

Another description of place relates to successful way-finding, where worldviews are deeply embedded in place, and where placenames tell stories (Tyrrell, 2006). Geographical markers of the past can signal messages from ancestors and "urge us to look for something important here" (Herman, 2013, p. 67).

Smith (2004) notes the whakapapa, wairuatanga, and inherited rights and obligations that Māori associate with belonging to a place. She draws on traditional waiata tangi to discuss the extent 
to which Māori feelings for, and emotional attachment to, ancestral lands could align with the western concept of "sense of place". Smith argues that "landscape (or place) had enduring significance for [ancestral] composers” (2004, p. 13). Strongly held, historically grounded, symbolic values are associated with a particular place. Concepts such as tūrangawaewae and tangatawhenuatanga, Smith argues, can be seen as evidence of a sense of place. Walker (2015) also describes how mōteatea and waiata, the songs of Māori, convey messages about whenua and whakapapa. She argues that if evaluators weave links between tangata whenua and themselves, and adhere to the values, protocols, and tikanga of the local people and place, their work will be more productive.

\section{Non-indigenous perspectives}

The notion of place for non-indigenous peoples is less well-considered in evaluation research, and this is where I had to cast the net wider. Authors from Aotearoa New Zealand and internationally, talk about how place is incorporated into the larger concept of self, and how community identity relates to physical landscape, interconnections, and complexities. Place is where the question "who am I?" can be answered, at least in part (Massey, 1994). For example, Gunn (2014) describes Wellington as the place that draws her home, where her ancestors are buried, and where the stories she makes begin.

Anderson and Jones (2009) concur that place is deeply woven into the fabric of human identity, and that people both influence and are influenced by the places they inhabit. They note that this interrelationship between people and place is a particular factor in rural settings. A community can be defined as a geographically bounded place where people interact together, and have a shared sense of belonging and identity (Scott, Park, \& Cocklin, 2000). The place acquires meaning as a result of those interactions. Duncan and Ley (1997, 
p. 316) describe the landscape as a text to be read with symbolic meanings and associations - much more than merely a physical location. From various writings, I gathered the following collection of words and phrases that capture some key expressions of place identity for non-indigenous peoples: "Landscape reference points", "visible and less visible symbols", "historic and cultural landmarks", "a place to stand", "a sense of belonging", "security", "an anchor", "community identity", "interconnections and complexities", "stewardship", "spiritual connections", and "intimate attachment".

Kearns (1997) describes how divergent, overlapping cultural values in the far north of Aotearoa New Zealand infuse people's constructions of place identity in uneven ways. He illustrates the hybridity of thinking and identity in bicultural communities, including locally understood vocabularies. In Whangaroa too, over 200 years, Māori and Pākehā have drawn on one another's knowledges and cultural practices to some extent and also remained apart in some ways. What they share is a sense of belonging in and to the place where they live their lives. This strong connection is illustrated in a long-running social media page where local stories and memories are shared and celebrated $^{2}$ by both Māori and Pākehā contributors.

\section{Place-conscious evaluation}

Having focused on developing a better understanding of the concept of place, I could now consider its influence on evaluation methodology. If we view place as a way of understanding, knowing, and learning about the world and the way that people relate; as the actual location of people's everyday struggles for meaning (Johnson, 2010) then what is it that we need to consider and listen to in place-conscious evaluation? How can we more consciously shape our methodology

2 Whangaroa County Old Photos (closed group). Retrieved from https://www.facebook.com/groups/448003928582975/ 
and anchor the evaluation with more explicit attention to critical elements of the place?

Thinking about the influence of place on evaluation methods is not new. In 1958, Arendt urged "learning about the lived experience of diverse others with our own eyes, but within their stories in their spaces and places" (in Greene, 2005, p. 16). This recognition of place continues in Kirkhart's (2010) argument that evaluation should be "explicitly understood as place-specific" (p. 407), and that evaluators should draw on community values, traditions, and customs to address issues of power, status, culture, and context. LaFrance et al. (2012) assert that a place-conscious methodology should be informed by core values that honour place and relate to a community's lived experiences and spiritual expressions, and that honouring a sense of place requires evaluation to fit within the contours of the location, including history and contemporary realities.

Anderson and Jones (2009) argue that place can be harnessed to enrich the research encounter and that the influence of place has often been overlooked. Holton \& Riley (2014) contend that narratives "in place" can help evaluators to get into "less easily storied places" (pp. $60,63)$ and reveal gaps in our understanding. Johnson (2010) considers deeper issues in promoting a place-based critical consciousness and a dialogue with place-connected knowledge systems, to reconnect with the depth of meaning of "our storied landscapes" (pp. 830832). He challenges us to consider whether, by detaching our work from place, we have developed an attitude that seeks to elevate our knowledge above that of others, particularly those who have a greater consciousness of place.

Place-conscious evaluation draws attention to the place where people involved in an evaluation project live their lives, the people who implement, make decisions about, and receive benefit from the programme, and how they live and work together in that place. 
Manning's question, "what sustains this community?" (p. 59), could be a useful starting point for thinking about place. A colleague briefly tells a story that illustrates the value of adding a place perspective to the evaluation process:

We had had a long day of meetings and towards the end of the day, the Principal interrupted us to say that he would like to take us for a drive. We piled into his car and for three hours he drove us up and down the valleys surrounding the school to show us where the children lived, and told us about the challenges they faced just to get to school. We had a different perspective then, which helped to make the evaluation process and findings more meaningful for both evaluators and participants.

There is a need to give more explicit consideration to the connections between people and place during method selection as these connections are integral to understanding the nature of local experience. Place-conscious evaluation urges evaluators not just to ask whose place this is, but also to consider what their role is within it. Kearns (1997) emphasises the need to clarify our own position in the community helping to "construct narratives with, rather than simply about local people and their place... to weave new patterns of understanding" (pp. 3, 7). He talks about how intimate knowledge of local dynamics and power supports reciprocal sense making.

The ANZEA 32011 Evaluator Competencies for Aotearoa New Zealand relating to contextual analysis and engagement align with Kearns' argument.

\section{Place-conscious evaluation design and practice}

There is a common theme in the literature that I reviewed. The way that interactions between people and place are understood, has

3 Aotearoa New Zealand Evaluation Association (ANZEA), Evaluation Competencies, Domain 1: Understanding the connections - people, place and relationships: whakapapa (genealogy), whenua (land), mana me te whanaungatanga (relationship). 
implications for the methods used and fundamentally differentiates one evaluation approach from another. Building awareness of place into evaluation proposals and design requires assessment of the implications of place during evaluation planning and implementation, decision making, and use. Rog, Fitzpatrick, and Conner (2012) argue that conscious assessment of context formalises, and provides a way to recognise and act on, an aspect that "evaluators sometimes only consider fleetingly or unconsciously" (pp. 103-104). In a place-conscious methodology, evaluators consider how the people describe their own place, the values and knowledges that relate to that place, and the importance of place to community and individual wellbeing, belonging, and identity.

Place-conscious evaluators are interested in:

- what the landscape markers of the past are telling them (names, languages, symbols, geographical features, and boundaries)

- how spiritual and ancestral connections are expressed and what is celebrated here

- significant historical and current social relationships, traditions and responsibilities in the communities (sensitivities, hidden differences, vocabularies, and ways of knowing)

- how community and individual identities are connected with the features of this place

- whose values, knowledges, spaces and stories are shared, and whose are ignored, or misrepresented.

Place-conscious evaluators also consider where they stand in the place they are engaging with, and how they can work together to develop a shared understanding of place. They ask what is significant in relation to this place for these people, and whether they are really talking to the people who matter here. These approaches help to establish trusting relationships with those involved. They can help to 
identify the extent to which the programme itself is place based and to delve into gaps in the information being gathered. A place-conscious evaluation design can help evaluators to focus inquiry in ways that are more meaningful to specific communities and to develop a greater understanding of the effect that the evaluation might have on real people's lives and experiences.

Greene (2005) argues that a place-conscious approach is particularly relevant to those who are traditionally ill-served by evaluation. Sharpening our focus on place in communities where there is great need could help to more clearly identify policy direction and target resources where and how they are most likely to have an impact. This view has influenced my sense of urgency in promulgating the notion of place-conscious evaluation methodologies in Te Tai Tokerau.

\section{Conclusion}

There is considerable depth of knowledge about the concept of place and its influence on personal and community identity, wellbeing, values, cultural mores, and social relationships. The literature identifies the primacy of place as an aspect of context and the deep significance of place for both indigenous and non-indigenous peoples. Many theorists assert that ways of knowing are place-bound.

The purpose of this inquiry has been to raise evaluators' consciousness of place. It promotes the development of evaluation methodology that shifts thinking from discrete reviews of isolated programmes within a community to a more holistic view of value, worth and effectiveness, from a community and place perspective. There is potential for further thinking about the influence of place on evaluation methodology, and the development of a specific framework for placeconscious evaluation. Like indigenous and transformative evaluations, place-conscious evaluations "begin two steps back from where many other evaluations begin” (Cram \& Mertens, 2016, p. 180). 
It is my hope that a greater consciousness of place in the design and practice of evaluation, particularly in my own and other Te Tai Tokerau communities, can:

- help evaluators reach across boundaries to consider complex communities in greater depth

- enable policy makers to respond better to the needs and aspirations of these communities

- be used by and within communities to address equity issues, influence policy decisions, and enhance their lived experiences and quality of life within that specific place

- be a catalyst for sustainable positive change as it engages families and communities in the evaluation process and enhances the value that they place on evaluative thinking.

To conclude, I reiterate Friere's assertion, "to engage with community requires us to engage with place" (in Johnson, 2010, p. 835), and pose Windsor and McVey's question, "do we have the wit to listen" (2005, p. 159). 


\section{Glossary of Māori terms}

This glossary draws on Moorfield (n.d.).

\begin{tabular}{|c|c|}
\hline awa & river \\
\hline kaitiakitanga & guardianship \\
\hline kaumātua & elder person(s) of status \\
\hline mana & prestige, influence, status, spiritual power, charisma \\
\hline Māori & indigenous person of Aotearoa New Zealand \\
\hline \multirow[t]{2}{*}{ marae } & open area for formal interaction in front of a meeting \\
\hline & house, often used for the whole complex \\
\hline maunga & mountain \\
\hline moana & harbour or ocean waters \\
\hline mōteatea & $\begin{array}{l}\text { lament, traditional chant, sung poetry - a general term for } \\
\text { songs sung in traditional mode }\end{array}$ \\
\hline Pākehā & New Zealander of European descent \\
\hline \multirow[t]{2}{*}{ pepeha } & set form of tribal saying, making whakapapa connections \\
\hline & with people and places (maunga, awa, marae) \\
\hline pou & marker post, pillar, sustenance \\
\hline pangata whenua & indigenous people of the land \\
\hline Te Tai Tokerau & Northland, Aotearoa New Zealand \\
\hline tupuna & ancestor \\
\hline tūrangawaewae & the place where one has rights of residence and belonging \\
\hline & through kinship \\
\hline waiata & song \\
\hline waiata tangi & song of lament or mourning \\
\hline wairua & spirit, soul, quintessence \\
\hline whakapapa & genealogy, lineage, descent, to connect in proper order \\
\hline whakataukī & proverb, a significant and formulaic saying \\
\hline whenua & land \\
\hline
\end{tabular}




\section{References}

Anderson, J., \& Jones, K. (2009). The difference that place makes to methodology: uncovering the "lived space" of young people's spatial practices. Children's Geographies, 7(3), 291-303. https://doi.org/10.1080/14733280903024456

Aotearoa New Zealand Evaluation Association (ANZEA). (2011). Evaluator competencies for Aotearoa New Zealand. Retrieved from http://www.anzea.org.nz/wp-content/uploads/2013/05/110801_anzea_ evaluator_competencies_final.pdf

Brown, D. (2014). Türangawaewae kore: Nowhere to stand. Paper presented at the Indigenous Homelessness Workshop, Winnipeg, Canada. Unpublished paper retrieved from http://ion.uwinnipeg.ca/-epeters/Workshop\%20Papers/Brown.pdf

Cadogan, T. (2004). A three-way relationship: God, land, people. In H. Bergin, \& S. Smith (Eds.), Land and place, he whenua he wähi: Spiritualities from Aotearoa New Zealand (pp. 27-43). Auckland: Accent Publications.

Coombes, B. (2013). Indigenism, public intellectuals, and the forever opposed: Or, the makings of a "Hori academic". In D. M. Mertens, F. Cram, \& B. Chilisa (Eds.), Indigenous pathways into social research: Voices of a new generation (pp. 71-88). Walnut Creek, CA: Left Coast Press.

Cram, F., \& Mertens, D. M. (2016). Negotiating solidarity between indigenous and transformative paradigms in evaluation. Evaluation Matters-He Take Tó Te Aromatawai, 2, 161-189. http://dx.doi.org/10.18296/em.0015

Dahler-Larsen, P., \& Schwandt, T. A. (2012). Political culture as context for evaluation. New Directions for Evaluation, 135, 75-87. https://doi.org/10.1002/ev.20028

Duncan, J., \& Ley, D. (Eds.). (1997). Place/culture/representation. London, UK: Routledge. 
Greene, J. C. (2005). Context. In S. Mathison (Ed.), Encyclopedia of evaluation. California: SAGE Publications.

Gruenewald, D. A. (2003). Foundations of place: A multidisciplinary framework for place-conscious education. American Educational Research Journal, 40(3), 619-654. https://doi.org/10.3102/00028312040003619

Gunn, K. (2014). Thorndon Wellington and home: My Katherine Mansfield project. Wellington: Bridget Williams Books. https://doi.org/10.7810/9781927277447

Herman, R. (2013). In a canoe: Intersections in space, time, and becoming. In J. T. Johnson, \& S. C. Larsen (Eds.), A deeper sense of place: Stories and journeys of collaboration in indigenous research (pp. 55-72). Corvallis, OR: Oregon State University Press.

Holton, M., \& Riley, M. (2014). Talking on the move: Place-based interviewing with undergraduate students. Area, 46(1), 59-65. https://doi.org/10.1111/area.12070

Johnson, J. T. (2010). Place-based learning and knowing: Critical pedagogies grounded in indigeneity. GeoJournal, 77(6), 829-836. https://doi.org/10.1007/s10708-010-9379-1

Johnson, J. T., \& Larsen, S. C. (Eds.). (2013). A deeper sense of place: Stories and journeys of collaboration in indigenous research. Corvallis, OR: Oregon State University Press.

Kearns, R. A. (1997). Constructing (bi)cultural geographies: Research on, and with, people of the Hokianga district. New Zealand Geographer, 53(2), 3-8. https://doi.org/10.1111/j.1745-7939.1997.tb00492.x

Kirkhart, K. E. (2010). Eyes on the prize: Multicultural validity and evaluation theory. American Journal of Evaluation, 31, 400-413. https://doi.org/10.1177/1098214010373645

LaFrance, J., Nichols, R., \& Kirkhart, K. E. (2012). Culture writes the script: On the centrality of context in indigenous evaluation. New Directions for Evaluation, 135, 59-74. https://doi.org/10.1002/ev.20027 
Manning, R. (2012). Place-based education: Helping early childhood teachers give meaningful effect to the tangata whenuatanga competency of Tātaiako and the principles of Te Whāriki. In D. Gordon-Burns, A. C. Gunn, K. Purdue, \& N. Surtees (Eds.), Te Aotūroa Tätaki: Inclusive early childhood education-Perspectives on inclusion, social justice and equity from Aotearoa New Zealand (pp. 57-74). Wellington: NZCER Press.

Moorfield, J. (n.d..) Te Aka Mãori-English, English-Māori dictionary. Retrieved from http://www.maoridictionary.co.nz/index.cfm

Massey, D. (1994). Space, place and gender. Cambridge, UK: Blackwell Publishers.

Neuman, W. L. (2006). Social research methods: Qualitative and quantitative approaches. Boston, MA: Pearson/Allyn and Bacon.

Independent Panel. (2012). Ngäpuhi speaks: Independent report on Ngāpubi Nui Tonu claim. Te Kawariki and Network Waitangi Whangarei.

Penetito, W. (2009). Place-based education: Catering for curriculum, culture and community. New Zealand Annual Review of Education, 18, 5-29.

Rog, D. J., Fitzpatrick, J. L., \& Conner, R. F. (Eds.). (2012). New Directions for Evaluation, 135.

Scott, K., Park, J., \& Cocklin, C. (2000). From "sustainable rural communities" to "social sustainability": Giving voice to diversity in Mangakahia Valley, New Zealand. Journal of Rural Studies, 16, 433-446. https://doi.org/10.1016/S0743-0167(00)00018-8

Smith, A. (2004). A Māori sense of place? Taranaki waiata tangi and feelings for place. New Zealand Geographer, 60(1), 12-17. https://doi.org/10.1111/j.1745-7939.2004.tb01700.x

Todd, R. (2012). Visibility, core standards, and the power of the story: Creating a visible future for school libraries. Teacher Librarian, 39(6), $8-14$.

Tyrrell, M. (2006). From placelessness to place: An ethnographer's experience of growing to know places at sea. Worldviews, 10(2), 220-238. https://doi.org/10.1163/156853506777965785 
Urlich Cloher, D. E. (2004). A perspective on early Māori relationships with land. In H. Bergin, \& S. Smith (Eds.), Land and place, he whenua he wähi: Spiritualities from Aotearoa New Zealand (pp. 45-57). Auckland: Accent Publications.

Walker, R. (2015). Pānui. Unpublished internal document, Education Review Office.

Ward, K., Maher, E. J., Marcynyszyn, L. A., Ellis, M. L. K., \& Pecora, P. J. (2011). Context matters: Real-world and utilization-focused evaluation strategies to support change and improvement in child welfare.

Child Welfare, 90(2), 29-47.

Windsor, J. E., \& McVey, J. A. (2005). Annihilation of both place and sense of place. Geographical Journal, 171(2), 146-165.

https://doi.org/10.1111/j.1475-4959.2005.00156.x

\section{The author}

\section{Maxine Dignan}

Evaluator

Education Review Office

Email: Maxine.Dignan@ero.govt.nz

(The opinions expressed are the author's own, not those of the Education Review Office.) 